\title{
Role of microRNAs as Clinical Cancer Biomarkers for Ovarian Cancer: A Short Overview
}

\author{
Cristina Elena Staicu ${ }^{1,2,+}$, Dragoș-Valentin Predescu ${ }^{3, \dagger}$, Călin Mircea Rusu 1,4, \\ Beatrice Mihaela Radu 1,5,+迆, Dragos Cretoiu ${ }^{6,7}$ (D) Nicolae Suciu ${ }^{7}$, Sanda Maria Crețoiu ${ }^{6, *}$ (D) \\ and Silviu-Cristian Voinea ${ }^{8}$
}

1 Department of Anatomy, Animal Physiology and Biophysics, Faculty of Biology, University of Bucharest, 91-95 Splaiul Independenței, 050095 Bucharest, Romania; elena.necsulescu@drd.unibuc.ro (C.E.S.); calin.rusu@nipne.ro (C.M.R.); beatrice.radu@bio.unibuc.ro (B.M.R.)

2 Center for Advanced Laser Technologies (CETAL), National Institute for Laser, Plasma and Radiation Physics, 409 Atomiștilor St., 77125 Măgurele, Romania

3 Department of General Surgery, Sf. Maria Clinical Hospital, 'Carol Davila' University of Medicine and Pharmacy, 37-39 Ion Mihalache Blvd., 011172 Bucharest, Romania; drpredescu@yahoo.com

4 Department of Life and Environmental Sciences, 'Horia Hulubei' National Institute of Physics and Nuclear Engineering, 30 Reactorului, 077125 Măgurele, Romania

5 Life, Environmental and Earth Sciences Division, Research Institute of the University of Bucharest (ICUB), University of Bucharest, 91-95 Splaiul Independenţei, 050095 Bucharest, Romania

6 Department of Cell and Molecular Biology and Histology, Carol Davila University of Medicine and Pharmacy, 8 Eroii Sanitari Blvd., 050474 Bucharest, Romania; dragos@cretoiu.ro

7 Fetal Medicine Excellence Research Center, 'Alessandrescu-Rusescu' National Institute of Mother and Child Health, 120 Lacul Tei Blvd., 020395 Bucharest, Romania; nsuciu54@yahoo.com

8 Department of Surgical Oncology, Alexandru Trestioreanu Oncology Institute, 'Carol Davila' University of Medicine and Pharmacy, 252 Fundeni Rd., 022328 Bucharest, Romania; dr.voineasilviu@gmail.com

* Correspondence: sanda@cretoiu.ro

+ Authors have contributed equally.

Received: 24 November 2019; Accepted: 6 January 2020; Published: 9 January 2020

\begin{abstract}
Ovarian cancer has the highest mortality rate among gynecological cancers. Early clinical signs are missing and there is an urgent need to establish early diagnosis biomarkers. MicroRNAs are promising biomarkers in this respect. In this paper, we review the most recent advances regarding the alterations of microRNAs in ovarian cancer. We have briefly described the contribution of miRNAs in the mechanisms of ovarian cancer invasion, metastasis, and chemotherapy sensitivity. We have also summarized the alterations underwent by microRNAs in solid ovarian tumors, in animal models for ovarian cancer, and in various ovarian cancer cell lines as compared to previous reviews that were only focused the circulating microRNAs as biomarkers. In this context, we consider that the biomarker screening should not be limited to circulating microRNAs per se, but rather to the simultaneous detection of the same microRNA alteration in solid tumors, in order to understand the differences between the detection of nucleic acids in early vs. late stages of cancer. Moreover, in vitro and in vivo models should also validate these microRNAs, which could be very helpful as preclinical testing platforms for pharmacological and/or molecular genetic approaches targeting microRNAs. The enormous quantity of data produced by preclinical and clinical studies regarding the role of microRNAs that act synergistically in tumorigenesis mechanisms that are associated with ovarian cancer subtypes, should be gathered, integrated, and compared by adequate methods, including molecular clustering. In this respect, molecular clustering analysis should contribute to the discovery of best biomarkers-based microRNAs assays that will enable rapid, efficient, and cost-effective detection of ovarian cancer in early stages. In conclusion, identifying the appropriate microRNAs as clinical biomarkers in ovarian cancer might improve the life quality of patients.
\end{abstract}


Keywords: ovarian cancer; microRNA; biomarker; early diagnosis; molecular clustering analysis

\section{Introduction}

Ovarian cancer occupies a leading position worldwide, and it is considered to be one of the most lethal cancers. In the United States, there are 22,530 new cases estimated for 2019, while the mortality is estimated to be 13,980 deaths in the same year [1]. Ovarian tumors are classified according to the tissue of origin according to the World Health Organization (WHO) classification of ovarian neoplasms, as follows: surface epithelial (65\%), germ cell (15\%), sex cord-stromal (10\%), metastases $(5 \%)$, and miscellaneous [2]. The most common form of ovarian cancer, epithelial ovarian cancer (EOC), represents more than $90 \%$ of malignant tumors and is the fifth leading cause of cancer-related death among women [3]. Recent progress was made in understanding the fundamental biology of this disease. However, this did not influence the mortality rate which has been stagnant since the 80s. It is necessary for a thorough screening based on the presence of biomarkers in conjunction with imaging explorations in order to increase the chances of detection of ovarian cancer in the early stages. Today, ovarian cancer is detected in advanced stages (stage III or IV) at the earliest stage II, based on transvaginal ultrasonography and increasing levels of CA 125 because of the absence of symptomatology [4]. The urgency to find reliable bio screening markers to assure early-stage diagnosis is high.

The definition of a biomarker differs slightly between the National Cancer Institute's (NCI), which considers that it must be an indicator of an existing process in the body 'a biological molecule found in blood, other bodily fluids, or tissues that is a sign of a normal or abnormal process, or of a condition or disease' [5], and that of $\mathrm{WHO}$, which considers it to be an indicator of the evolution of the disease 'any substance, structure or process that can be measured in the body or its products and influence or predict the incidence of outcome or disease' [6]. Regardless of the definition, it is clear that an ideal biomarker is a substance or molecule that can be readily detected while using non-invasive methods, which are most likely found in blood or urine. Besides, its presence must provide reliable data on the diagnosis, evolution, and prognosis of the disease. Currently, among the biomarkers that are considered to have potential in the early detection and monitoring of different types of cancer, there are the small, highly conserved non-coding RNA molecules-microRNAs (miRNAs).

miRNAs are involved in the regulation of gene expression in a range of developmental and physiological processes, while their dysregulation has been associated with all types of cancer. The first miRNA, lin-4, was discovered in Caenorhabditis elegans at the beginning of the 1990s [7]. miRNAs are a class of single-stranded, short segments of RNA (of $\sim 22 \mathrm{nt}$ ) that can suppress gene expression by binding to complementary segments of messenger RNA and interfere with the formation of proteins by translation $[8,9]$. In detail, miRNAs interact with target mRNAs and consequently induce mRNA degradation and/or repression of their translation [10]. In most cases, miRNAs interact with the $3^{\prime}$ untranslated region ( $3^{\prime}$ UTR) of mRNA, but their interaction with other regions was also reported, such as the $5^{\prime}$ UTR, coding sequence, and gene promoters [11]. The miRNAs are synthesized in the nucleus as primary miRNAs (pri-miRNAs), being cleaved by enzymes, like Drosha and Pasha, into precursor miRNAs (pre-miRNAs), and are then transferred into the cytoplasm through the nuclear pores [10,11]. Once in the cytoplasm, pre-miRNAs are cleaved again by Dicer enzymes to form 22 nucleotide long mature miRNAs (Figure 1). Mature miRNAs will become part of the RNA-induced silencing complex (RISC), a multiprotein complex (for more details, see an extensive review by [12]. 


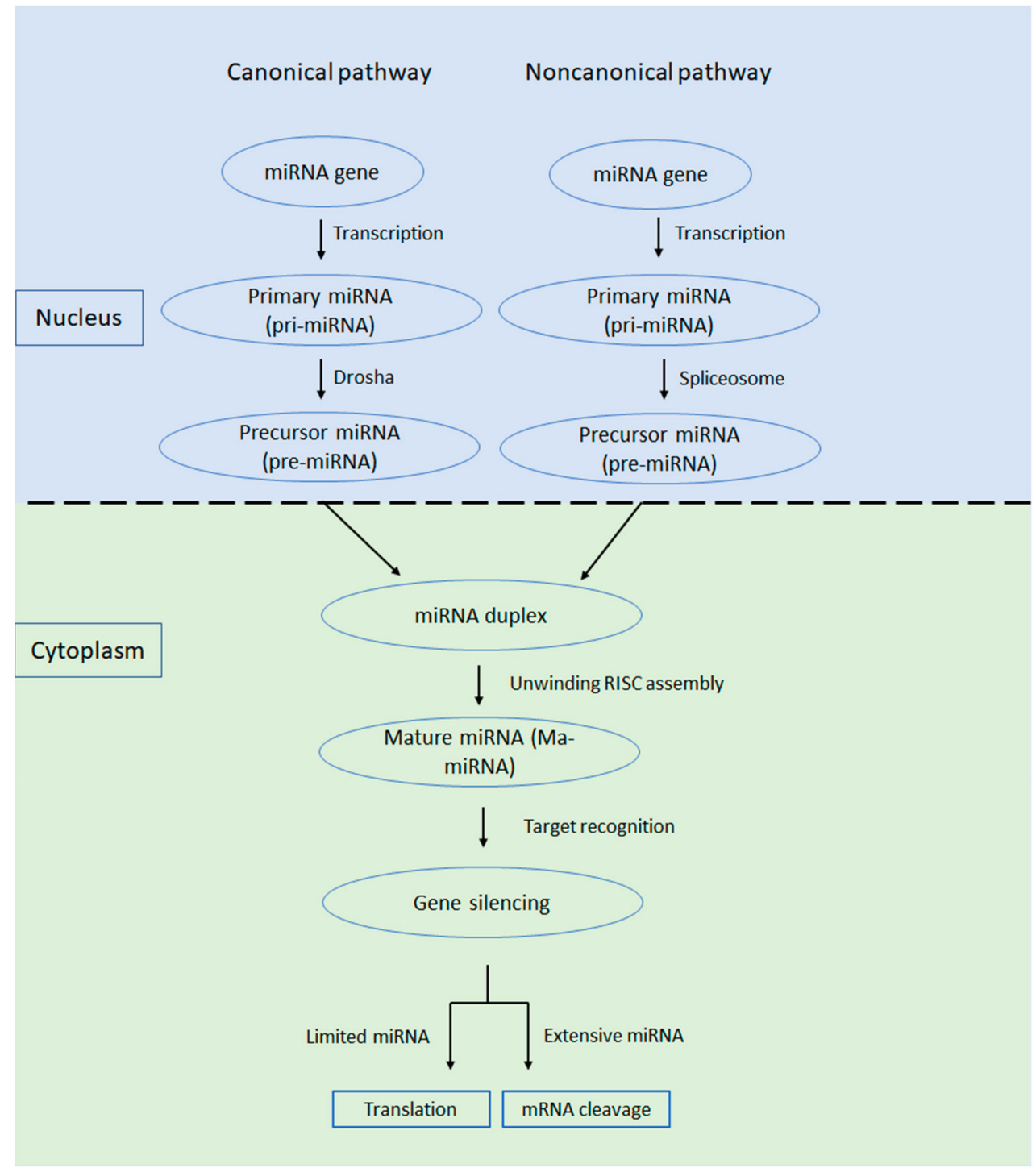

Figure 1. miRNA biogenesis involves five steps: 1. Transcription. Most miRNAs genes are transcribed by RNA polymerase II. However, a few miRNAs genes use RNA polymerase III. The initial long primary transcript is named primary microRNA (pri-miRNA) and is a hairpin containing transcript with imperfect double-stranded regions. 2. First Cleavage. The Microprocessor complex formed by DROSHA nuclease and RNA-binding protein DGCR8 removes the $5^{\prime}$ and $3^{\prime}$ ends of the pri-miRNA. The result is a pre-microRNA (pre-miRNA), a short hairpin of about 60 to $70 \mathrm{nt}$. 3. Nuclear export. pre-miRNA is translocated through nuclear pore into the cytoplasm, and after that, it is bound up and form a complex with Exportin-5, Ran, and GTP. 4. Second cleavage. In the cytoplasm, the pre-miRNA interacts with RNA-Induced Silencing Complex (RISC) loading complex (DICER1, plus an Argonaute protein and either TARBP2 or PRKRA) and is cleaved by DICER1 to a double-stranded miRNA (21 to 23 nucleotides) with a two-nucleotide $3^{\prime}$ overhang of 2-3 nt. 5. Incorporation into RNA-RISC and strand selection. The double-stranded miRNA is passed to the Argonaute protein where the passenger strand, will be removed and degraded, while the guide strand (the less Table $5^{\prime}$ end), will be selected. RISC can now regulate the gene expression of the mRNA transcript.

miRNAs, which typically target tumor-suppressive protein-coding transcripts, are classified as onco-miRs and are found to be upregulated in different types of cancer [13]. On the contrary, miRNAs, which are responsible for the downregulation of oncogenes, are known as tumor suppressor miRNAs and are often lost in cancer [14]. 
In the human genome, a number of approximately 1000 miRNAs have been identified until now by bioinformatic analyses, and it suggested that they contribute to regulating almost $60 \%$ of the transcriptome [15]. Nowadays, more and more new genes encoding miRNAs are being described in the literature, with their expression greatly differing from tissue to tissue, which leads to the idea of using miRNAs as biomarkers [16]. Some tumor types have a specific miRNA signature, which, if determined, could be indicative of the existence, progression, and metastasis [17]. Numerous studies that are focused on studying miRNAs expression in cancer showed that some miRNAs behave as tumor-promoting miRNAs (oncomiRNAs and metastamiRNAs), while others are responsible for tumor suppression [18]. Figure 2 aids us in comprehensively understanding the oncomiRNAs association and involvement in etiology, evolution, and prognostic. While taking the oncogenic potential and the tumor-suppressive function of miRNAs into account, it is currently believed that we could detect new strategies for cancer therapy by manipulating miRNAs expression levels. Wong et al. launched OncomiR a user-friendly online resource for exploring miRNA dysregulation in cancer and allow flexible miRNomic analysis across many cancer types [19].

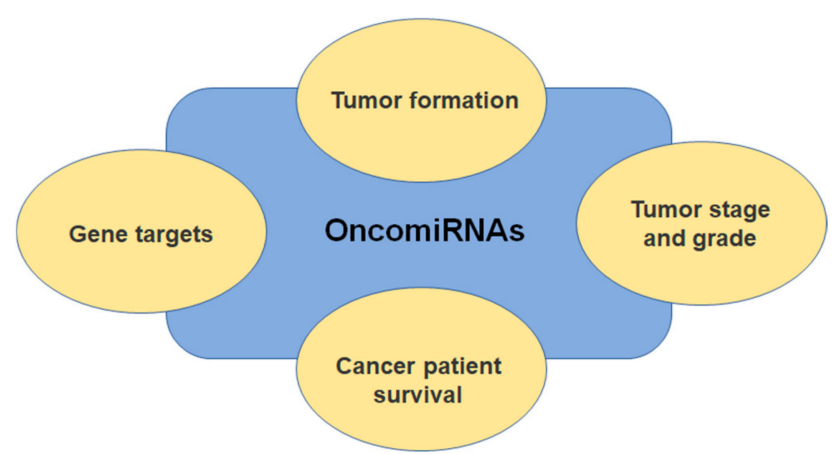

Figure 2. OncomiRNAs shown promise in cancer studies due to their stability and specificity to cells and tumors. Observe their association with gene targeting, tumor formation, cancer patient survival, and tumor stage and grade. OncomiRNAs associations raise the possibility of anticancer therapeutics by using miRNA inhibitors.

The clinical importance of miRNAs has been demonstrated for several types of cancer, including ovarian cancer [20]. The tendency is to determine the extracellular miRNAs that are present in various body fluids, which are stable because they are packed in extracellular vesicles [21].

Several review studies have summarized the potential role of circulating nucleic acids in the diagnostic and prognostic of ovarian cancer [22-24]. In detail, Giannopoulou et al. described recent advances on circulating tumor cells and circulating tumor DNA based on liquid biopsy analysis in ovarian cancer and their potential in diagnosis, prognostic and predictive tumor biomarkers [22]. Additionally, it was highlighted the potential of circulating miRNAs in the diagnosis and prognostic of epithelial ovarian carcinoma, with special attention to the subtypes of ovarian cancer, the sample size, the sample subtype (i.e., miRNAs in body fluids), the method of detection, and the survival correlation etc. [23,24]. However, these reviews were limited to the analysis of circulating RNAs/DNAs as biomarkers in ovarian cancer. Our review is focused on the therapeutic potential of miRNAs in ovarian cancer and integrates information regarding circulating miRNAs with their expression changes in ovarian tumors and in ovarian cancer cell lines to offer a new perspective on their quantification in different environments to increase the robustness and reproducibility of using certain miRNAs as reliable biomarkers for the diagnosis/prognosis of this pathology.

\section{Types of miRNAs in Ovarian Cancer (Circulating Cell-Free and Exosomal miRNAs)}

Free circulating miRNAs are considered to be valuable biomarkers in multiple pathologies. After their biogenesis, miRNAs are secreted from cells, and they can be found in a variety of body fluids, such as plasma/serum, saliva, urine, breast milk, cerebrospinal fluid, ascites, pleural effusion, and vaginal 
discharge [22-29]. Circulating miRNAs can be encountered as cell-free miRNAs that are bound in specific association with protein Argonaute 2 (AGO2) or high-density lipoproteins (HDLs) encapsulated in extracellular vesicles (EVs) of three types: exosomes, microvesicles, and apoptotic bodies [9,30-32]. Exosomes contain only a small fraction of circulating miRNAs [33], while larger vesicles (microvesicles or oncosomes) contain the majority of circulating miRNAs, as well as larger RNAs [34].

There is no doubt that circulating cell-free miRNA are considered to be clinically relevant for ovarian cancer diagnosis, prognosis, and therapeutics [35]. However, multiple issues concerning the standardization of miRNA processing, from sample collection and sample storage to RNA isolation, RNA reverse-transcription, and data analyses, should be solved before considering miRNA as reliable biomarkers for current clinical use, despite the great clinical potential of miRNA [36]. Additionally, miRNA are commonly packaged in exosomes, and multiple exosomal miRNAs have been considered as biomarkers in ovarian cancer [37-39]. As in the case of miRNA processing, similar concerns exist regarding the standardization of exosomes separation, purification, and analysis [40], which are responsible for hampering the clinical use of exosomal miRNAs in ovarian cancer diagnosis, prognosis, and therapeutics.

The miRNA profile detected in circulating tumor exosomes found in the plasma obtained from ovarian cancer patients was considered to be similar to the miRNA profile in cellular ovarian tumors. Several miRNAs, such as miR-21, miR-141, miR-200a, miR-200b, miR-200c, miR-203, miR-205, and miR-214, were found in the plasma of these patients [41]. miR-30a-5p was detected in exosomes that were extracted from the urine of ovarian serous adenocarcinoma patients and might serve as a promising diagnostic and therapeutic target [42]. Ovarian cancer ascites also contain miR-21, miR-23b, miR-29a, and it is considered that exosomes that are derived from ovarian cancer effusion supernatants are responsible for inducing more aggressive disease [23].

Zhang et al. demonstrated that plasma exosomes from patients with ovarian cancer and healthy women differently expressed miRNAs through high-throughput sequencing: 34 were found to be upregulated and 31 downregulated, respectively. The hsa-miR-106a-5p, hsa-let-7d-5p, and hsa-miR-93-5p expression levels were significantly increased, whereas hsa-miR-122-5p, hsa-miR-185-5p, and hsa-miR-99b-5p were significantly decreased in patients with ovarian cancer comparative with healthy controls [43]. Another study that deals with circulating miRNA profiling in plasma samples of ovarian cancer patients detected a variety of differentially expressed miRNAs, among some of them, are confirmed as possible biomarkers by other studies, e.g., hsa-miR-144-3p, hsa-miR-337-5p, hsa-miR-500a-5p, hsa-miR-26b-5p, hsa-miR-125a-3p, and hsa-miR-19b-3p [44]. Moreover, the expression of miRNAs seems to be different in high-grade serous ovarian carcinoma (HGSC), clear cell ovarian carcinoma (CCC), and ovarian surface epithelium (OSE). miR-509-3-5p and miR-509-5p differentiate CCC from HGSC, while miR-200c-3p is considered to be associated with survival in HGSC patients [45].

Exosomal miR-373, miR-200a, miR-200b, and miR-200c were detected in the serum of EOC patients, and there is a correlation between the increased levels of miR-200b and miR-200c and CA125 values, suggesting that these microRNAs may be involved in tumor progression [37].

\section{Ovarian Cancer and miRNA Expression Profiles}

Multiple miRNAs have been considered as potential clinical cancer biomarkers, particularly in ovarian cancer, and their expression profiles have been analyzed in ovarian cancer cell lines (Table 1), in xenograft mice models for ovarian cancer (Table 2), in surgically excised specimens from ovarian cancer patients (Table 3), or in the serum/plasma of ovarian cancer patients (Table 4). 
Table 1. miRNA in ovarian cancer cell lines.

\begin{tabular}{|c|c|c|}
\hline miRNA & Type of Ovarian Cells & Changes in Ovarian Cancer \\
\hline $\operatorname{miR}-23 b$ & $\begin{array}{l}\text { OVCAR3, HO8910-PM, } \\
\text { SKOV3/DDP cells }\end{array}$ & $\begin{array}{l}\text { miR-23b transfection slows down cell growth, blocks } \\
\text { cell cycle in G1, increases the number of apoptotic } \\
\text { cells, and reduces the rate of cell migration [46] }\end{array}$ \\
\hline miR-26a & SKOV-3, ES2 cells & $\begin{array}{l}\text { Overexpression of miR-26b in ovarian cancer } \\
\text { cells [47] } \\
\text { miR26-b is involved in tumor progression by } \\
\text { targeting estrogen receptor alpha (ER } \alpha) \text { [47] }\end{array}$ \\
\hline $\operatorname{miR}-125 b$ & SKOV3 cells & $\begin{array}{l}\text { Overexpression or downregulation of miR- } 125 \mathrm{~b} \text { did } \\
\text { not affect the in vivo cancer cells proliferation and } \\
\text { apoptosis [48] }\end{array}$ \\
\hline $\operatorname{miR}-125 b$ & SKOV3, ES2 cells & $\begin{array}{l}\text { Low expression of miR- } 125 \mathrm{~b} \text { in ovarian tumor cells } \\
\text { Through overexpression of miR-125b, tumor } \\
\text { proliferation is prevented by controlling the G2 phase } \\
\text { of the cell cycle and by targeting the BCL3 gene [ } 49 \text { ] }\end{array}$ \\
\hline miR-141 & $\begin{array}{l}\text { Ovarian cancer cells (SKOV3, } \\
\text { OVCA433, and A2780cp) } \\
\text { Cervical cancer cells (OV2008 } \\
\left.\text { and } C 13^{*}\right)\end{array}$ & $\begin{array}{l}\text { miR-141 increases anchorage-independent growth } \\
\text { and survival of ovarian cancer cells in vitro [50] } \\
\text { miR-141 enhances anoikis resistance in metastatic } \\
\text { tumor progression by targeting the Kruppel-related } \\
\text { zinc finger protein AP-2rep (KLF12)/specificity } \\
\text { protein } 1 \text { (Sp1)/survivin axis }\end{array}$ \\
\hline $\begin{array}{l}\operatorname{miR}-145 \\
\operatorname{miR}-133 b\end{array}$ & $\begin{array}{l}\text { Ovarian cancer cells }(3 \mathrm{AO}, \\
\text { SKOV3) }\end{array}$ & $\begin{array}{l}\text { miR-145 promotes miR-133b expression through } \\
\text { c-myc and DNMT3A-mediated methylation in } \\
\text { ovarian cancer cells [51] } \\
\text { miR-133b upregulation mediates the inhibitory } \\
\text { activity of miR-145, in aerobic glycolysis conditions } \\
\text { (i.e., Warburg effect), by targeting hexokinase-2 (HK2) } \\
\text { in ovarian cancer cells [51] }\end{array}$ \\
\hline miR-146a & $\begin{array}{l}\text { Epithelial ovarian cancer cells } \\
\text { (OVCAR3, CAOV3, HEY) } \\
\text { Normal ovarian cells (HOSE) }\end{array}$ & $\begin{array}{l}\text { Through overexpression, it acts as a tumor } \\
\text { suppressor, but through its downregulation, it } \\
\text { inhibits apoptosis, increases proliferation and } \\
\text { chemoresistance [52] }\end{array}$ \\
\hline $\operatorname{miR}-146 b$ & $\begin{array}{l}\text { Epithelial ovarian cancer cells } \\
\text { (SKOV3, OVCAR3, HO8910, } \\
\text { A2780) }\end{array}$ & $\begin{array}{l}\text { miR-146b overexpression upregulates VIM and ZO-1 } \\
\text { and consequently inhibits tumor dissemination [53] }\end{array}$ \\
\hline $\operatorname{miR}-148 a$ & $\begin{array}{l}\text { Ovarian cancer cells (SKOV3, } \\
\text { OVCAR, and A2780) } \\
\text { Normal ovarian epithelial cells } \\
\text { (HUM-CELL-0088) }\end{array}$ & $\begin{array}{l}\text { Downregulation of miR-148a in ovarian cancer } \\
\text { cells [54] } \\
\text { miR-148a inhibits migration and invasion of ovarian } \\
\text { cancer cells via targeting sphingosine-1-phosphate } \\
\text { receptor 1 (S1PR1) [54] }\end{array}$ \\
\hline miR-200a-3p & $\begin{array}{l}\text { Ovarian cancer cells (ES2, } \\
\text { HO8919PM, SKOV3, HO8910) } \\
\text { Ovarian surface epithelial cells } \\
\text { (HOSEpiC) }\end{array}$ & $\begin{array}{l}\text { Overexpression of miR-200a-3p strongly promotes } \\
\text { the proliferation, colony formation and invasion of } \\
\text { ovarian cancer cells [55] } \\
\text { Binds the } 3^{\prime}-\text { UTR of PCDH9 and decreased the } \\
\text { expression of PCDH9 [55] }\end{array}$ \\
\hline miR-337-3p & $\begin{array}{l}\text { Ovarian cancer cells (ES2, A2780, } \\
\text { SKOV-3, OVCAR-3) }\end{array}$ & $\begin{array}{l}\text { miR-337-3p inhibits cell proliferation and decreases } \\
\text { the PI3K/AKT signaling pathway activation } \\
\text { (its targets are PIK3CA and PIK3C) [56] } \\
\text { Its ectopic expression inhibits proliferation and } \\
\text { induces apoptosis and cell cycle arrest in G0/G1 } \\
\text { phase [56] }\end{array}$ \\
\hline miR-433 & $\begin{array}{l}\text { Ovarian cancer cells (SKOV3 } \\
\text { and OVCAR3) }\end{array}$ & $\begin{array}{l}\text { miR-433 inhibits migration and invasion of ovarian } \\
\text { cancer cells via targeting Notch1 [57] }\end{array}$ \\
\hline
\end{tabular}


Table 1. Cont.

\begin{tabular}{|c|c|c|}
\hline miRNA & Type of Ovarian Cells & Changes in Ovarian Cancer \\
\hline $\operatorname{miR}-630$ & Ovarian cancer cells (SKOV3) & $\begin{array}{l}\text { miR-630 overexpression stimulates in vitro cell } \\
\text { proliferation and migration [58] } \\
\text { miR-630 targets directly Krüppel-like factor } 6 \text { (KLF6) } \\
\text { in ovarian cancer cells [58] }\end{array}$ \\
\hline miR-802 & $\begin{array}{l}\text { Epithelial ovarian cancer cells } \\
\text { (OVCAR3, SKOV3, A2780, and } \\
\text { CAOV3) } \\
\text { Normal ovarian surface } \\
\text { epithelial cells (HOSEpiC) }\end{array}$ & $\begin{array}{l}\text { miR-802 is downregulated in epithelial ovarian } \\
\text { cancer cell lines [59] } \\
\text { Overexpression of miR-802 suppresses migration, } \\
\text { proliferation, invasion and induces apoptosis in } \\
\text { epithelial ovarian cancer cell lines [59] } \\
\text { miR-802 directly targets Monooxygenase/Tryptophan } \\
\text { 5-Monooxygenase Activation Protein Zeta (YWHAZ) } \\
\text { gene in epithelial ovarian cancer cells [59] }\end{array}$ \\
\hline $\operatorname{miR}-1271$ & $\begin{array}{l}\text { Ovarian cancer cells (SKOV3 } \\
\text { and CAOV3) } \\
\text { Normal ovarian cells (IOSE80) }\end{array}$ & $\begin{array}{l}\text { Suppresses cell viability and invasion in ovarian } \\
\text { cancer cells [60] } \\
\text { Directly binds the 3'-UTR of ZEB1 mRNA and } \\
\text { regulates the expression of ZEB1 [60] }\end{array}$ \\
\hline
\end{tabular}

Table 2. miRNA in ovarian cancer tissue-animal model studies.

\begin{tabular}{|c|c|c|}
\hline miRNA & Type of Ovarian Tissue & Changes in Ovarian Cancer \\
\hline $\mathrm{miR}-23 \mathrm{~b}$ & $\begin{array}{l}\text { Nude mice injected subcutaneously with } \\
\text { mock or hsa-miR-23b-transfected OVCAR3 } \\
\text { cells }\end{array}$ & $\begin{array}{l}\text { miR-23b induces downregulation of cyclin G1 } \\
\text { (CCNG1) in tumor xenografts and reduction } \\
\text { of tumor size in mice [46] }\end{array}$ \\
\hline miR-26a & $\begin{array}{l}\text { Nude mice injected subcutaneously with } \\
\text { SKOV3 cells transfected with miR-26a or } \\
\text { anti-miR-26a }\end{array}$ & $\begin{array}{l}\text { miR-26a is involved in cell proliferation and } \\
\text { tumor development in epithelial ovarian } \\
\text { cancer induced in animal models [47] }\end{array}$ \\
\hline $\operatorname{miR}-125 b$ & $\begin{array}{l}\text { Nude mice inoculated with SKOV3 cells that } \\
\text { were transfected with the vector control, } \\
\text { miR-125b mimic or inhibitor }\end{array}$ & $\begin{array}{l}\text { miR-125b inhibits the in vivo cancer cell } \\
\text { migration and invasion }[48]\end{array}$ \\
\hline $\operatorname{miR}-125 b$ & $\begin{array}{l}\text { Nude mice injected subcutaneously with } \\
\text { SKOV3 cells transfected with miR-125b or } \\
\text { anti-miR-125b }\end{array}$ & $\begin{array}{l}\text { miR-125b suppresses the development of } \\
\text { ovarian cancer [49] }\end{array}$ \\
\hline $\operatorname{miR}-141$ & $\begin{array}{l}\text { BALB/cAnN nude mice injected } \\
\text { intraperitoneal with stable SKOV3 } \\
\text { miR-141-expressing clones, or A2780cp shSu } \\
\text { knockdown clone and the scrambled controls }\end{array}$ & $\begin{array}{l}\text { miR-141 increases tumor growth in vivo and } \\
\text { induces the appearance of a great number of } \\
\text { macroscopic tumor nodules, especially in the } \\
\text { omentum and the peritoneal cavity [50] }\end{array}$ \\
\hline $\operatorname{miR}-146 b$ & $\begin{array}{l}\text { Nude mice injected with control cells or cells } \\
\text { overexpressing miR-146b }\end{array}$ & $\begin{array}{l}\text { Overexpression of miR- } 146 \mathrm{~b} \text { reduces cell } \\
\text { migration and decreases the level of F-box } \\
\text { and leucine-rich repeat protein } 10 \text { (FBXL10) } \\
\text { protein [53] }\end{array}$ \\
\hline miR-337-3p & $\begin{array}{l}\text { Xenograft models of ovarian cancer induced } \\
\text { by inoculation of A2780 and OVCAR- } 3 \text { cells } \\
\text { in female BALB/c athymic nude mice }\end{array}$ & $\begin{array}{l}\text { miR-337-3p is a tumor suppressor that } \\
\text { controls the expression of p110 } \alpha \text { and } p 110 \beta \\
\text { (i.e., PIK3CA and PIK3CB encoded } \\
\text { proteins) [56] } \\
\text { Tumors injected with miR-337-3p agomiR } \\
\text { grew more slowly than those injected with } \\
\text { agomiR-NC for both xenograft models [56] }\end{array}$ \\
\hline $\operatorname{miR}-630$ & $\begin{array}{l}\text { Balb/c mice injected subcutaneously with } \\
\text { SKOV3 cells transfected with inhibitors, } \\
\text { mimics or negative control of miR- } 630\end{array}$ & $\begin{array}{l}\text { miR- } 630 \text { overexpression stimulates in vivo } \\
\text { ovarian cancer proliferation [58] }\end{array}$ \\
\hline
\end{tabular}


Table 3. miRNA in ovarian cancer tissue-clinical studies.

\begin{tabular}{|c|c|c|}
\hline miRNA & Type of Ovarian Tissue & Changes in Ovarian Cancer \\
\hline $\operatorname{miR}-125 b$ & $\begin{array}{l}\text { Surgical resection of tumor tissues and } \\
\text { the corresponding adjacent normal } \\
\text { tissues in epithelial ovarian cancer } \\
\text { patients }\end{array}$ & $\begin{array}{l}\text { miR-125b is downregulated in ovarian cancer [ } 48 \text { ] } \\
\text { miR-125b suppresses ovarian cancer progression } \\
\text { via suppression of the epithelial-mesenchymal } \\
\text { transition pathway by targeting the SET protein } \\
\text { (binds directly to the SET } 3^{\prime} \text {-UTR) [48] }\end{array}$ \\
\hline miR-141 & $\begin{array}{l}\text { Surgical specimens of ovarian cancer } \\
\text { and normal ovarian tissues }\end{array}$ & $\begin{array}{l}\text { miR-141 is upregulated in clinical ovarian cancer } \\
\text { samples having a } \sim 10 \text {-fold higher expression than } \\
\text { in normal ovary tissues [50] }\end{array}$ \\
\hline $\begin{array}{l}\operatorname{miR}-133 b \\
\operatorname{miR}-145\end{array}$ & $\begin{array}{l}\text { Human normal ovarian tissue samples } \\
\text { and ovarian carcinomas (e.g., serous } \\
\text { cancer, mucinous, endometrioid cancer, } \\
\text { clear cell cancer) }\end{array}$ & $\begin{array}{l}\text { miR-145 and miR- } 133 \mathrm{~b} \text { were downregulated in } \\
\text { endothelial ovarian cancer, their expression being } \\
\text { positively correlated [51] }\end{array}$ \\
\hline miR-148a & $\begin{array}{l}\text { Surgical resection of ovarian cancer } \\
\text { tissue and their matched normal } \\
\text { adjacent tissues }\end{array}$ & $\begin{array}{l}\text { Downregulation of miR-148a in ovarian cancer } \\
\text { tissue [54] }\end{array}$ \\
\hline miR-200a-3p & $\begin{array}{l}\text { Surgically excised tissue from ovarian } \\
\text { cancer patients }\end{array}$ & $\begin{array}{l}\text { miR-200a-3p expression was negatively } \\
\text { correlated with the PCDH9 expression in ovarian } \\
\text { cancer [55] }\end{array}$ \\
\hline $\operatorname{miR}-337-3 p$ & $\begin{array}{l}\text { Surgically excised epithelial ovarian } \\
\text { cancer specimens }\end{array}$ & $\begin{array}{l}\text { Downregulation of miR-337-3p in epithelial } \\
\text { ovarian cancer tissues and correlated with the } \\
\text { pathological grade of patients [56] }\end{array}$ \\
\hline miR-433 & $\begin{array}{l}\text { Surgical resections of ovarian cancer } \\
\text { tissues and matched normal ovary } \\
\text { tissues }\end{array}$ & $\begin{array}{l}\text { Downregulation of miR- } 433 \text { expression and } \\
\text { upregulation of Notch1 expression in ovarian } \\
\text { cancer tissues compared with normal ovarian } \\
\text { tissues [57] }\end{array}$ \\
\hline miR-630 & $\begin{array}{l}\text { Surgically excised ovarian cancer and } \\
\text { normal ovarian tissue samples }\end{array}$ & miR-630 is upregulated in ovarian cancer [58] \\
\hline miRNA-802 & $\begin{array}{l}\text { Surgical specimens of epithelial ovarian } \\
\text { cancer and adjacent normal tissues }\end{array}$ & $\begin{array}{l}\text { Down-regulation in epithelial ovarian cancer } \\
\text { specimens [59] }\end{array}$ \\
\hline miR-1271 & $\begin{array}{l}\text { Surgical specimens of ovarian cancer } \\
\text { tissues and peritumoral normal tissues }\end{array}$ & $\begin{array}{l}\text { Inverse correlation between miR-1271 expression } \\
\text { and ZEB1 in ovarian cancer tissues [60] }\end{array}$ \\
\hline
\end{tabular}

There is a need for a specificity of at least $99.6 \%$, sensitivity of at least $75 \%$, and a positive predictive value of at least $10 \%$ to be considered as effective tools to be able to detect early stages in ovarian cancer patients, especially if one aim to use liquid biopsies [61]. There are few relevant studies for the importance of circulating miRNAs in the early diagnosis of ovarian cancer. The first one was performed by Taylor et al. in 2008, when eight exosomal miRNAs: miR-21, miR-141, miR-200a, miR-200b, miR-200c, miR-203, miR-205, and miR-214 were reported to be elevated in the sera of ovarian cancer patients and identical to microRNAs from ovarian tumor cells, while the same exosomal miRNAs were absent in the normal controls [41]. Taylor and collaborators concluded at that time that these microARNs could be used as surrogate diagnostic markers for biopsy profiling [41].

Over time, in the search for finding a convenient and effective method for early detection of cancer, based on the use of liquid biopsy and with high sensitivity, several other papers were published. As, for example, the one by Resnick et al., which describes a novel real-time PCR microarray detection method [62]. This study provides evidence that eight miRNAs determined in human serum that were obtained from untreated ovarian cancer patients were significantly differentially expressed between the cancer and normal specimens. Among miRNAs-21, 92, 93, 126, and 29a, which were significantly over-expressed in the serum from cancer patients compared to controls, they identified three potential oncomirs: mirs-21, 92, and 93 present in the serum of patients with normal CA-125 [62]. 
In 2015, Gao et al. identified microRNA-200c and microRNA-141 in the serum of 74 epithelial ovarian cancer patients, and validated the results while using the area under the ROC curve (AUC) and Kaplan-Meier curve and the log-rank test to detect the prognostic value of these microARNs [63].

Zuberi et al. suggested by Trizol method, where miR-200a, miR-200b, and miR-200c overexpressions are associated with the aggressive tumor progression [64]. In addition, Meng et al. found elevated levels of circulating exosomal microRNAs while using TaqMan MicroRNA assays and ELISA. The study was performed in a cohort of 163 epithelial ovarian cancer, and increased levels of exosomal miR-200b and miR-200c mainly observed in advanced EOC patients, while the levels of miR-373 and miR-200a were increased in all FIGO stages [37].

A more recent study developed an optimal detection method after a japanese national project that was entitled Development and Diagnostic Technology for Detection of miRNA in Body Fluids was launched. Among 13 types of cancer, they also included, as an objective, the development of a novel screening strategy capable of discriminating ovarian cancer patients from healthy women. Using 28 cases of ovarian tumors, Yokoi et al. validated their model in an independent cohort and obtained a high accuracy (sensitivity, 0.99; specificity, 1.00) [65].

Table 4. miRNA in serum/plasma of ovarian cancer patients.

\begin{tabular}{|c|c|c|}
\hline miRNA & Serum/Plasma & Changes in Ovarian Cancer \\
\hline miR-26a & Plasma & $\begin{array}{l}\text { Upregulation of miR-26a in human epithelial ovarian } \\
\text { cancer [47] }\end{array}$ \\
\hline $\begin{array}{c}\text { miRNA-21 } \\
\text { miRNA-29a } \\
\text { miRNA-92 } \\
\text { miRNA-93 } \\
\text { miRNA-99b } \\
\text { miRNA-126 } \\
\text { miRNA-127 } \\
\text { miRNA-155 }\end{array}$ & Serum & $\begin{array}{l}\text { Upregulation of miRNA-21, miRNA-29a, miRNA-92, } \\
\text { miRNA-93, miRNA-126 in ovarian cancer [62] } \\
\text { Downregulation of miRNA-99, miRNA-127, } \\
\text { miRNA-155 in ovarian cancer [62] }\end{array}$ \\
\hline miR-145 miR-133b & Serum & $\begin{array}{l}\text { Expression of miR- } 145 \text { and miR-133b is significantly } \\
\text { decreased in the serum of patients with ovarian } \\
\text { cancer [51] }\end{array}$ \\
\hline miR-193a-5p & Serum & $\begin{array}{l}\text { Combined detection of miR-193-5p, HE } 4 \text { and CA125 } \\
\text { improves the diagnostic efficacy of epithelium } \\
\text { ovarian cancer [66] }\end{array}$ \\
\hline $\begin{array}{c}\text { miR-19a-3p } \\
\text { miR-30a-5p } \\
\text { miR-645 } \\
\text { miR-150-5p } \\
\text { miR-191-5p } \\
\text { miR-206 } \\
\text { miR-34c-5p } \\
\text { miR-548a-3p miR-320a } \\
\text { miR-574-3p } \\
\text { miR-590-5p } \\
\text { miR-106b-5p }\end{array}$ & Plasma & $\begin{array}{l}\text { Downregulation of miR-19a-3p, miR-30a-5p, } \\
\text { miR-645, miR-150-5p in ovarian cancer [67] } \\
\text { Upregulation of miR-191-5p, miR-206, miR-34c-5p, } \\
\text { miR-548a-3p, miR-320a, miR-574-3p, miR-590-5p, } \\
\text { miR-106b-5p in ovarian cancer [67] }\end{array}$ \\
\hline
\end{tabular}

Several other miRNAs are thought to bring useful information for an early diagnosis of ovarian cancer. The most important data are corroborated in Table 4.

\section{4. miRNAs in Ovarian Cancer Invasion and Metastasis}

In general, in ovarian cancer, metastasis is promoted by the epithelial-to-mesenchymal transition (EMT), and miRNAs are related to the regulation of signaling proteins that are involved in the control of EMT [68]. Different miRNAs modulate EMT-associated signaling genes. miR-7 is critical in the 
reversion of EMT due to AKT and ERK1/2 pathways inactivation, by reducing the epidermal growth factor receptor (EGFR) expression and thus inhibiting tumor metastasis [69]. It was suggested by Zhou et al. to be a future therapeutic target for ovarian cancer metastasis intervention [70]. miR-150 is usually downregulated in epithelial ovarian cancer and it is considered as an independent prognostic biomarker that is unique to metastases [71]. miR-150 inhibits cell invasion and metastasis by targeting transcriptional repressor Zinc Finger E-Box Binding Homeobox 1 (ZEB1) and suppressing it [72]. Although miR-146a was suggested to act as a tumor suppressor through the down-regulation of the NFkB activators IRAK1 and TRAF6 [73], another mechanism seems to be responsible for increased survival [71]. The low expression of miR-146a is considered to be of poor prognosis and suggestive of an unfavorable outcome in patients with epithelial ovarian cancer [74]. Some other miRNAs, miR-22, miR-183, and miR-31, have a negative effect on Tiam1 expression and they are responsible for the suppression of cell migration and invasion of serous ovarian carcinoma [75].

miR-17-5p influences ovarian cancer progression, which also influences EMT by targeting PTEN signaling. Experimental studies that were performed on OVCAR-3 and SKOV-3 cell lines showed that miR-17-5p increased migration, while the administration of an anti-miR-17-5p inhibitor decreased the migration and invasion of ovarian cancer cells [76].

Recent studies have demonstrated that exosomes-contained miRNAs have an important contribution to the cell-to-cell communication [13,77]. In particular, this type of intercellular communication that is based on exosomes-contained miRNAs is involved in the metastasis process that is associated with multiple subtypes of cancer [78], including ovarian cancer [79].

\section{5. miRNAs and Chemotherapy Sensitivity}

Tumor cell resistance to chemotherapeutic agents is a major problem in cancer treatment. Recent studies point to miRNAs as potential therapeutic agents that may play an important role in modulating the tumor cells' sensitivity to different drugs [80].

Several studies focused on the effects of miRNAs in modulating the ovarian cancer cells' sensitivity to chemotherapeutic agents (e.g., cisplatin, paclitaxel). Vang et al. demonstrated that miR-150 and miR-146a had distinct effects on cisplatin tolerance in ovarian cancer cells, with miR-150 moderately increasing cisplatin tolerance (i.e., IC50) in SKOV-3 cells, but not in OVCAR-8 and IGROV-1 cells, while miR-146a was ineffective [71]. Zou et al. demonstrated that miR-630 decreased cell proliferation and increased ovarian cancer cells (A2780 and SKOV3) sensitivity to cisplatin, due to its ability to modulate phosphatase and tensin homolog (PTEN) expression in these cells [81]. Additionally, Yang et al. demonstrated that miR-214 increased the ovarian cancer cells (e.g., HIOSE-80, MCC-3, A2780S, and OV119) resistance to cisplatin, by targeting PTEN, which in turn activated the PI3K-Akt pathway and further increased ovarian cancer cell proliferation [82]. Pink et al. have also shown that miR-21-5p increased sensitivity to cisplatin while using ovarian cancer cells (A2780), while miR-21-3p increased their resistance to the drug by targeting neuron navigator 3 (NAV3) gene [83]. Li et al. also demonstrated that miR-137 increased the sensitivity to cisplatin of ovarian cancer cells (SKOV-3 and A2780) and increased the number of apoptotic cancer cells, by regulating the expression of the X-linked inhibitor of apoptosis protein (XIAP) [84]. Additionally, Tian et al. demonstrated that miR-595 overexpression suppressed ovarian cancer cell proliferation, colony formation, and invasion, and that miR-595 sensitized ovarian cancer cells to cisplatin by targeting ATP-binding cassette sub-family B member 1 (ABCB1) [85].

Paclitaxel is another drug used to treat ovarian cancer, to which some tumor cells are resistant. It has been revealed that the inhibition miR-106a and miR-591 expression decreased the level of tumor cells resistance to paclitaxel, as both types of miRNAs are involved in the regulation of pro-apoptotic genes, such as tumor necrosis factor (TNF) ligand/receptor and caspase families. These effects are associated with the capacity of miR-106a and miR-591 to directly target genes that encode for Zinc finger E-box-binding homeobox 1 (ZEB1), B-cell lymphoma/leukemia 10 (BCL 10), and caspase-7 [86]. Additionally, miR-146 increased tumor cell (CAOV3 cells) sensitivity to paclitaxel by downregulating 
the expression of superoxide dismutase 2 (SOD2) [52], although it was ineffective in regulating the sensitivity to cisplatin [71].

Helleman et al. highlighted the resistance of ovarian cancer cells to chemotherapy drugs (e.g., paclitaxel and cisplatin), due to changes that occur in the extracellular matrix, alterations that lead to resistance to chemotherapy, but also to cancer progression. The authors argued the role of the transforming growth factor-beta (TGF beta) in gene clusters that are associated with the extracellular matrix. miR-200 downregulation targets TGF beta, which in turn stimulates tumor proliferation, cancer cell metastasis [87], and chemotherapy resistance of ovarian tumor cells [88]. One benefit of miRNA in chemotherapy is that the overexpression of miR can induce sensitivity to several drugs at the same time in tumor cells. In ovarian cancer, miR-146b inhibited the expression of F-box and leucine-rich repeat protein 10 (FBXL10) and also upregulated Cyclin D1, vimentin (VIM), and zona-occludens-1 (ZO-1) [53]. Additionally, Yan et al. demonstrated, in SKOV-3, OVCAR-3, HO8910, and A2780 cells, that the overexpression of miR-146b can induce cisplatin and paclitaxel sensitivity, and also confirmed the results of in vivo experiments on nude mice [53]. To resume, the authors pointed out that the overexpression of the miR-146b slowed the progression of malignancy, while miR-146b downregulation had opposite effects [53].

The low expression of miR-133b [89], miR-186 [90], and miR-873 [91] in A2780 and OVCAR-3 cells was associated with the upregulation of drug-resistance-related genes. Studies aiming to identify their role in ovarian cancer have shown that all of these three miRNAs mediate glutathione S-transferase- $\pi$ (GST- $\pi$ ) and multidrug resistance protein 1 (MDR1) modulation via targeting ATP-binding cassette targeting sub-family B [MDR/TAP], member 1 (ABCB1) [90-92]. Thus, by the overexpression of miR-133b, miR-186, and miR-873, the expression of the genes mentioned above were downregulated in tumor cells, being accompanied by an increased sensitivity of ovarian cancer cells to cisplatin and paclitaxel [89-91]. However, by targeting the same genes, other miRNAs have opposite effects. In detail, miR-130b increased resistance in A2780 and A2780/Taxol cells for cisplatin and paclitaxel, by upregulating GST- $\pi$, MDR1, and P-glycoprotein (P-gp) [93]. Additionally, increased levels of miR-490-3P in A2780 and A2780/Taxol tumor cells decreased the paclitaxel sensitivity and upregulated GST- $\pi$, MDR1 and P-gp [89,94]. Another oncomiR, miR-181a-5p, was described by Petrillo et al. in tumor cells that were isolated from biopsies of patients who received neoadjuvant chemotherapeutic treatment. miR-181a-5p was demonstrated to activate the TGF-beta pathway, resulting in increased cell resistance to platinum treatments [95]. To resume, miRNAs can modulate the activity of several genes that are involved in apoptosis, DNA repair, or drug resistance in tumor cells, so that it may be seen as a possible future approach in cancer treatment [96].

\section{6. miRNAs and Their Therapeutic Potential}

In conventional chemotherapy treatment, drugs, such as topoisomerase inhibitors, inhibitors of microtubule polymerization, alkylating agents, antimetabolites, platinum agents, and hormonal agents, which have the role of disrupting the cell cycle and inhibiting cell division, are frequently used [97]. Another approach in cancer therapy is the use of miRNAs as a strategy for obtaining safe treatments that are based on small molecules in different types of cancer [98].

The therapeutic potential of miRNAs can be exploited through the overexpression of miRNAs as tumor suppressors, while using synthetic miRNAs mimics $[99,100]$ or molecules that inhibit the activity of oncogenic miRNAs [101]. Some examples of the effects that are induced by miRNAs can be summarized:

- The inhibition of tumor proliferation, by the downregulation of genes and pathways involved in this process. In detail, miR-218 is targeting Runt-related transcription factor 2 (RUNX2) [102], miR-199a overexpression produces a downregulation of CD44 [103], miR-532-5p functions as a tumor suppressor by downregulation of casein kinase II subunit alpha 2 (CSNK2A2), SH3 and PX domain-containing protein 2A (SH3PXD2A), and Chromodomain-helicase-DNA-binding protein 4 (CHD4) [104], miR-222-3p and miR-221 reduce tumor cell proliferation by inhibiting 
AKT phosphorylation [105] and miR-135a-3p mediates the expression of Baculoviral IAP repeat-containing protein 3 (BIRC3), GAGRA3, and Sperm protein associated with the nucleus, X chromosome (SPANX) B1/SPANX B2 [106];

- Apoptosis of cancer cells, which occurs by miR-29b inducing PTEN hypomethylation (tumor suppressor), and, in turn, increases the expression of PTEN in cancer cells by directly binding to the 3'-UTR of PTEN [107]. miR-491-5p induces tumor cell apoptosis by inhibiting BCL-XL and EGFR signaling [108], and miR-744-5p induces tumor cell apoptosis in ovarian cancer by targeting Heterogeneous nuclear ribonucleoproteins C1/C2 (HNRNPC) and Nuclear factor 1 X-type (NFIX) [109];

- Reduction in the rate of migration and formation of tumor metastases: miR-200 regulates IL-8 and CXCL1 activity [110], miR-199a is targeting Hypoxia-inducible factor (HIF)- $1 \alpha$ and HIF-2 $\alpha$ [111], miR-92 $\alpha$ mediates the suppression of peritoneal metastasis by inhibiting $\alpha 5$ integrin [112] and miR-143-3p while using TGF-beta activated kinase 1 (TAK1) signaling [113];

- It affects tumorigenesis and chemosensitivity by modulating oxidative stress through the miR-141 and miR-200a regulation at the level of p38 $\alpha$ protein [114];

- Inhibition of upregulated oncogenic miRs by administration of antisense oligonucleotides and antagomirs or by locked nucleic acid constructs (LNA) [101,115];

- The use of therapeutic approaches based on miRNAs in cancer therapy can have multiple benefits. Among these benefits, the most important is the ease of miRNA administration and delivery. In comparison with other molecules used in gene therapy (e.g., large viral vectors or plasmids), miRNAs can be manipulated easier and delivered due to their low molecular weight and small size [94].

\section{Molecular Clustering Analysis in Ovarian Cancer}

The study of miRNAs facilitates the early clinical prognosis of ovarian cancer due to the recent advances in molecular clustering analysis methods. Advanced statistical analysis allows for the unbiased evaluation of patient cohorts, by pre-processing and analyzing relevant genes expressions.

Clustering methods subsume under the unsupervised learning techniques category and they are used for the classification of data by correlating similar relevant characteristics, with no predefined classes being required [116]. Statistical software packages (i.e., hclust in R) provide fast and optimizable tools for the minimization of inter-class similarity, along with the maximization of intra-class similarity. Studies suggest a non-linear trend in the relationship evaluation among the different species of miRNA; therefore, univariate analysis is often followed by hierarchical clustering [117]. Variability in miRNA expression datasets was evaluated by decomposition of data into isolated patterns, allowing for the application of singular-value decomposition methods. Principal component analysis (PCA) was employed for the identification of significant batch effects among the miRNA expression datasets, and empirical Bayes methods allowed for the adjustment of this effect.

A study by McDonald et al. highlighted the efficiency of variable-based approaches in the clustering of non-responding patients, followed by univariate analysis of biologically relevant variables, among which they evaluated the differential expression of miRNA [118]. miRNA expression patterns were identified and correlated with ovarian cancer samples through PCA [119-121], arriving at a highly differentiated profile among ovarian tumoral cell lines (e.g., OVCAR3, OVCAR420 etc), ovarian cancer tissues, and non-tumorigenic cells (HOSE-B). Another approach for determining differential expression between groups is constituted by the $t$-statistic method linear models for microarray data (LIMMA) [122]. The agglomerative hierarchical clustering method, as employed by Dahiya et al., used a complete linkage method to test the natural tumor samples grouping based on gene-expression profiles correlations [119].

Luo et al. introduced CoModule, a new cluster-based method for the identification of miRNA regulatory modules (MRMs). The MRMs are identified by determining the co-expression clusters through rough set clustering, applying least absolute shrinkage and selection operator (LASSO) 
regression to reconstruct the regulatory pairs of miRNA and mRNA and adding the targeted mRNA into the miRNA cluster [123]. The study also reported the increased efficiency of the LASSO model in achieving the best performance in terms of the specificity and sensitivity for ovarian cancer data.

The Maximum Weighted Merger Method (MWMM) approach facilitated the clustering of miRNAs and mRNAs that are based on their similar underlying causal factors in cancer. The method consists of a combination between the Hungarian algorithm [124] and the blossom algorithm [125] for the passive generation of clusters from a miRNA-mRNA bipartite graph [126]. Thus, the potential biomarkers can be identified to point out the precision targets for chemotherapy.

Neural networks proved to be highly efficient for ovarian cancer prognosis, as stated in a study by Elias et al., in which batch adjustments were performed before the analysis. The neural network expressed a high area under the curve (AUC) value of approximately 0.9 , in contrast to other classification models, on both pre-processed and raw data. The model that was employed was a multilayer perceptron with the number of hidden layers being optimized to avoid overfitting [127]. Differences in false-positive and false-negative assignment were compared while using Fisher's exact test, and by the use of 14 miRNAs from pre-and post-operative original signature, provided very good discriminatory power on the testing set (AUC $0.93,95 \%$ CI $0.81-1.00$ ), with an overall sensitivity of $75 \%$ and specificity of $100 \%$ [122].

A study by Hu et al. indicated a significant association between the identified miR-200 cluster through expression profiling analysis. Additionally, it has been reported that miR-200b-429 clusters were being co-regulated and targeting multiple genes playing a role in cancer. Therefore, they might be seen as predictive markers in ovarian cancer. In their predictive model, the links between the disease outcome and miRNA were tested while using the Cox Proportional-Hazard model, while the relationship between each miRNA and the outcome prognostic was carried out using the non-parametric Kaplan-Meier estimator [128].

Based on a training set from The Cancer Genome Atlas (TCGA) database, a Support Vector Machine (SVM) classifier, along with a recursive feature elimination (RFE) algorithm was built [129]. The miRNA categories were selected prior to classification by Cox regression analysis and RFE, arriving at an optimum of 19 miRNAs. The favorable AUC values of both training and validation sets $(>0.9)$ suggested a significant relationship between the SVM results and prognosis, therefore indicating that the classifier based on 19 miRNAs could evaluate the recurrence of ovarian cancer [130].

The computational limitations in the molecular cluster analysis of miRNA are increased by the high computational complexity of biological data processing. Therefore, $\mathrm{k}$-means clustering became highly employed in studies due to its low computational complexity [59]. Table 5 contains a detailed comparison between hierarchical and k-means clustering, while pondering on the advantages and disadvantages of miRNA data analysis.

Table 5. Hierarchical clustering vs. k-Means clustering in miRNA data analysis with relevance in ovarian cancer.

\begin{tabular}{ll}
\hline \multicolumn{1}{c}{ Hierarchical Clustering } & \multicolumn{1}{c}{ k-Means Clustering } \\
\hline $\begin{array}{l}\text { Can't handle large miRNA expression } \\
\text { data-quadratic complexity }\end{array}$ & $\begin{array}{l}\text { Can handle large miRNA expression datasets-linear } \\
\text { complexity }\end{array}$ \\
\hline $\begin{array}{l}\text { Reproducible as every miRNA expressed is assigned } \\
\text { a cluster, and the clustering occurs based on the } \\
\text { closeness of previously generated clusters. }\end{array}$ & $\begin{array}{l}\text { Unreproducible clustering due to the prerequisite of a } \\
\text { random number of clusters. }\end{array}$ \\
\hline $\begin{array}{l}\text { Produces more intuitive results in the form of a } \\
\text { dendrogram. }\end{array}$ & $\begin{array}{l}\text { Produces less intuitive results if data does not group } \\
\text { into hyper spherical clusters. }\end{array}$ \\
\hline $\begin{array}{l}\text { Poor performance and higher time of execution as the } \\
\text { number of generated clusters increases. }\end{array}$ & $\begin{array}{l}\text { Higher time of execution associated with large } \\
\text { miRNA expression datasets. }\end{array}$ \\
\hline
\end{tabular}




\section{Conclusions and Future Perspectives}

Ovarian cancer is characterized by a very high mortality rate being diagnosed at a late stage, which is mainly due to the lack of early detection tools. This review summarized the role of microRNAs as clinical cancer biomarkers for ovarian cancer. Screening serum/plasma miRNAs might contribute to improved prognosis of ovarian cancer, but first, there is a need to understand whether, how, and when miRNAs might be used as biomarkers. An important distinction should be made between miRNA as clinical biomarkers in the histological exam that is based on the analysis of surgically excised specimens from ovarian cancer patients and miRNAs as clinical biomarkers in serum/plasma of ovarian cancer patients. The miRNA expression profiles in patients' serum/plasma are more relevant for early diagnosis of ovarian cancer, while the miRNA expression profiles in histological specimens are only useful for intraoperative diagnosis confirmation. The most robust miRNA expression profiles are those that are tested in a variety of samples (e.g., ovarian cancer tissue obtained from surgical resections, plasma/serum from ovarian cancer patients, ovarian cancer cells, xenograft mice, etc.). However, many studies so far have focused on alterations of single microRNA or of a reduced number of selected microRNAs in ovarian cancer. Few studies have considered the validation of miRNA expression profiles by molecular clustering analysis.

In perspective, the choice of the best microRNAs-based assays, which were validated in both extensive clinical screenings and bioinformatics approaches, will enable rapid, efficient, and cost-effective detection of ovarian cancer in early stages. Furthermore, miRNA expression profiles may be affected by pharmacological treatments and, therefore, we can assume that they have the potential to serve as therapeutic targets/agents for the treatment of ovarian cancer.

Author Contributions: C.E.S. wrote Section 3 and organized the sections of the manuscript, D.-V.P. wrote Section 2 and edited the manuscript, C.M.R. wrote Section 7, B.M.R. wrote Section 4, D.C. wrote Section 5 and revised the final form of the manuscript, N.S. wrote Section 6, S.M.C. wrote Section 1 and drew Figures 1 and 2, S.-C.V. wrote Section 8. B.M.R. and S.-C.V. structured the information in Tables 1-3, C.E.S. and D.-V.P. structured the information in Tables 4 and 5. S.M.C., N.S., D.-V.P. and B.M.R. are responsible for the conceptualization of the manuscript. All authors have read and agreed to the published version of the manuscript.

Funding: This work was supported by a grant of the Romanian Ministry of Research and Innovation, PCCDI-UEFISCDI, project number PN-III-P1-1.2-PCCDI-2017-0833/68/2018, within PNCDI III.

Conflicts of Interest: The authors declare no conflict of interest.

\section{References}

1. NCI Surveillance, Epidemiology, and End Results Program. Cancer Stat Facts: Ovarian Cancer. Available online: https://seer.cancer.gov/statfacts/html/ovary.html (accessed on 14 October 2019).

2. Ehdaivand, S. WHO Classification of Ovarian Neoplasms. Available online: https://www.pathologyoutlines. com/topic/ovarytumorwhoclassif.html (accessed on 14 October 2019).

3. Lisio, M.A.; Fu, L.; Goyeneche, A.; Gao, Z.H.; Telleria, C. High-Grade Serous Ovarian Cancer: Basic Sciences, Clinical and Therapeutic Standpoints. Int. J. Mol. Sci. 2019, 20, 952. [CrossRef]

4. Elias, K.M.; Guo, J.; Bast, R.C., Jr. Early Detection of Ovarian Cancer. Hematol. Oncol. Clin. N. Am. 2018, 32, 903-914. [CrossRef] [PubMed]

5. NCI Dictionary of Cancer Terms: Biomarker. Available online: https://www.cancer.gov/publications/ dictionaries/cancer-terms/def/biomarker (accessed on 14 October 2019).

6. WHO international Programme on Chemical Safety Biomarkers in Risk Assessment: Validity and Validations. Available online: http://www.inchem.org/documents/ehc/ehc/ehc222.htm (accessed on 14 October 2019).

7. Lee, R.C.; Feinbaum, R.L.; Ambros, V. The C. elegans heterochronic gene lin-4 encodes small RNAs with antisense complementarity to lin-14. Cell 1993, 75, 843-854. [CrossRef]

8. He, L.; Hannon, G.J. MicroRNAs: Small RNAs with a big role in gene regulation. Nat. Rev. Genet. 2004, 5 , 522-531. [CrossRef] [PubMed]

9. Cretoiu, S.M. Circulating microRNAs in cardiovascular diseases: Recent progress and challenges. J. Hypertens. Res. 2016, 1, 15-18. 
10. Gregory, R.I.; Chendrimada, T.P.; Cooch, N.; Shiekhattar, R. Human RISC couples microRNA biogenesis and posttranscriptional gene silencing. Cell 2005, 123, 631-640. [CrossRef]

11. Roden, C.; Gaillard, J.; Kanoria, S.; Rennie, W.; Barish, S.; Cheng, J.; Pan, W.; Liu, J.; Cotsapas, C.; Ding, Y.; et al. Novel determinants of mammalian primary microRNA processing revealed by systematic evaluation of hairpin-containing transcripts and human genetic variation. Genome Res. 2017, 27, 374-384. [CrossRef]

12. Tafrihi, M.; Hasheminasab, E. MiRNAs: Biology, Biogenesis, their Web-based Tools, and Databases. Microrna 2019, 8, 4-27. [CrossRef]

13. Svoronos, A.A.; Engelman, D.M.; Slack, F.J. OncomiR or Tumor Suppressor? The Duplicity of MicroRNAs in Cancer. Cancer Res. 2016, 76, 3666-3670. [CrossRef]

14. Frixa, T.; Donzelli, S.; Blandino, G. Oncogenic MicroRNAs: Key Players in Malignant Transformation. Cancers 2015, 7, 2466-2485. [CrossRef]

15. Di Leva, G.; Croce, C.M. The Role of microRNAs in the Tumorigenesis of Ovarian Cancer. Front. Oncol. 2013, 3, 153. [CrossRef] [PubMed]

16. Londin, E.; Loher, P.; Telonis, A.G.; Quann, K.; Clark, P.; Jing, Y.; Hatzimichael, E.; Kirino, Y.; Honda, S.; Lally, M.; et al. Analysis of 13 cell types reveals evidence for the expression of numerous novel primate- and tissue-specific microRNAs. Proc. Natl. Acad. Sci. USA 2015, 112, E1106-E1115. [CrossRef] [PubMed]

17. Kamanu, T.K.; Radovanovic, A.; Archer, J.A.; Bajic, V.B. Exploration of miRNA families for hypotheses generation. Sci. Rep. 2013, 3, 2940. [CrossRef] [PubMed]

18. Gambari, R.; Brognara, E.; Spandidos, D.A.; Fabbri, E. Targeting oncomiRNAs and mimicking tumor suppressor miRNAs: Nuew trends in the development of miRNA therapeutic strategies in oncology (Review). Int. J. Oncol. 2016, 49, 5-32. [CrossRef] [PubMed]

19. Wong, N.W.; Chen, Y.; Chen, S.; Wang, X. OncomiR: An online resource for exploring pan-cancer microRNA dysregulation. Bioinformatics 2018, 34, 713-715. [CrossRef] [PubMed]

20. Almeida, M.I.; Reis, R.M.; Calin, G.A. MicroRNA history: Discovery, recent applications, and next frontiers. Mutat. Res. 2011, 717, 1-8. [CrossRef]

21. Cretoiu, D.; Xu, J.; Xiao, J.; Suciu, N.; Cretoiu, S.M. Circulating MicroRNAs as Potential Molecular Biomarkers in Pathophysiological Evolution of Pregnancy. Dis. Mark. 2016, 2016, 3851054. [CrossRef]

22. Erbes, T.; Hirschfeld, M.; Rucker, G.; Jaeger, M.; Boas, J.; Iborra, S.; Mayer, S.; Gitsch, G.; Stickeler, E. Feasibility of urinary microRNA detection in breast cancer patients and its potential as an innovative non-invasive biomarker. BMC Cancer 2015, 15, 193. [CrossRef]

23. Vaksman, O.; Trope, C.; Davidson, B.; Reich, R. Exosome-derived miRNAs and ovarian carcinoma progression. Carcinogenesis 2014, 35, 2113-2120. [CrossRef]

24. Tokuhisa, M.; Ichikawa, Y.; Kosaka, N.; Ochiya, T.; Yashiro, M.; Hirakawa, K.; Kosaka, T.; Makino, H.; Akiyama, H.; Kunisaki, C.; et al. Exosomal miRNAs from Peritoneum Lavage Fluid as Potential Prognostic Biomarkers of Peritoneal Metastasis in Gastric Cancer. PLoS ONE 2015, 10, e0130472. [CrossRef]

25. Weber, J.A.; Baxter, D.H.; Zhang, S.; Huang, D.Y.; Huang, K.H.; Lee, M.J.; Galas, D.J.; Wang, K. The microRNA spectrum in 12 body fluids. Clin. Chem. 2010, 56, 1733-1741. [CrossRef] [PubMed]

26. Xie, Z.; Yin, X.; Gong, B.; Nie, W.; Wu, B.; Zhang, X.; Huang, J.; Zhang, P.; Zhou, Z.; Li, Z. Salivary microRNAs show potential as a noninvasive biomarker for detecting resectable pancreatic cancer. Cancer Prev. Res. (Phila.) 2015, 8, 165-173. [CrossRef] [PubMed]

27. Akers, J.C.; Ramakrishnan, V.; Kim, R.; Skog, J.; Nakano, I.; Pingle, S.; Kalinina, J.; Hua, W.; Kesari, S.; Mao, Y.; et al. MiR-21 in the extracellular vesicles (EVs) of cerebrospinal fluid (CSF): A platform for glioblastoma biomarker development. PLoS ONE 2013, 8, e78115. [CrossRef] [PubMed]

28. Shin, Y.M.; Yun, J.; Lee, O.J.; Han, H.S.; Lim, S.N.; An, J.Y.; Lee, K.H.; Lee, K.M.; Choe, K.H. Diagnostic Value of Circulating Extracellular miR-134, miR-185, and miR-22 Levels in Lung Adenocarcinoma-Associated Malignant Pleural Effusion. Cancer Res. Treat. 2014, 46, 178-185. [CrossRef] [PubMed]

29. Liu, J.; Sun, H.; Wang, X.; Yu, Q.; Li, S.; Yu, X.; Gong, W. Increased exosomal microRNA-21 and microRNA-146a levels in the cervicovaginal lavage specimens of patients with cervical cancer. Int. J. Mol. Sci. 2014, 15, 758-773. [CrossRef] [PubMed]

30. Schwarzenbach, H.; Nishida, N.; Calin, G.A.; Pantel, K. Clinical relevance of circulating cell-free microRNAs in cancer. Nat. Rev. Clin. Oncol. 2014, 11, 145-156. [CrossRef]

31. Anfossi, S.; Babayan, A.; Pantel, K.; Calin, G.A. Clinical utility of circulating non-coding RNAs-An update. Nat. Rev. Clin. Oncol. 2018, 15, 541-563. [CrossRef] 
32. Fabbri, M. MicroRNAs and miRceptors: A new mechanism of action for intercellular communication. Philos. Trans. R. Soc. Lond. B Biol. Sci. 2018, 373. [CrossRef]

33. Chevillet, J.R.; Kang, Q.; Ruf, I.K.; Briggs, H.A.; Vojtech, L.N.; Hughes, S.M.; Cheng, H.H.; Arroyo, J.D.; Meredith, E.K.; Gallichotte, E.N.; et al. Quantitative and stoichiometric analysis of the microRNA content of exosomes. Proc. Natl. Acad. Sci. USA 2014, 111, 14888-14893. [CrossRef]

34. Morello, M.; Minciacchi, V.R.; de Candia, P.; Yang, J.; Posadas, E.; Kim, H.; Griffiths, D.; Bhowmick, N.; Chung, L.W.; Gandellini, P.; et al. Large oncosomes mediate intercellular transfer of functional microRNA. Cell Cycle 2013, 12, 3526-3536. [CrossRef]

35. Nakamura, K.; Sawada, K.; Yoshimura, A.; Kinose, Y.; Nakatsuka, E.; Kimura, T. Clinical relevance of circulating cell-free microRNAs in ovarian cancer. Mol. Cancer 2016, 15, 48. [CrossRef] [PubMed]

36. Faraldi, M.; Gomarasca, M.; Banfi, G.; Lombardi, G. Free Circulating miRNAs Measurement in Clinical Settings: The Still Unsolved Issue of the Normalization. Adv. Clin. Chem. 2018, 87, 113-139. [CrossRef] [PubMed]

37. Meng, X.; Muller, V.; Milde-Langosch, K.; Trillsch, F.; Pantel, K.; Schwarzenbach, H. Diagnostic and prognostic relevance of circulating exosomal miR-373, miR-200a, miR-200b and miR-200c in patients with epithelial ovarian cancer. Oncotarget 2016, 7, 16923-16935. [CrossRef] [PubMed]

38. Pan, C.; Stevic, I.; Muller, V.; Ni, Q.; Oliveira-Ferrer, L.; Pantel, K.; Schwarzenbach, H. Exosomal microRNAs as tumor markers in epithelial ovarian cancer. Mol. Oncol. 2018, 12, 1935-1948. [CrossRef]

39. Kobayashi, M.; Sawada, K.; Nakamura, K.; Yoshimura, A.; Miyamoto, M.; Shimizu, A.; Ishida, K.; Nakatsuka, E.; Kodama, M.; Hashimoto, K.; et al. Exosomal miR-1290 is a potential biomarker of high-grade serous ovarian carcinoma and can discriminate patients from those with malignancies of other histological types. J. Ovarian Res. 2018, 11, 81. [CrossRef]

40. Deftu, A.T.; Radu, B.M.; Cretoiu, D.; Deftu, A.F.; Cretoiu, S.M.; Xiao, J. Exosomes as intercellular communication messengers for cardiovascular and cerebrovascular diseases. In Exosomes; Edelstein, L., Smythies, J., Quesenberry, P., Noble, D., Eds.; Academic Press, Elsevier Inc.: Amsterdam, The Netherlands, 2020; pp. 199-238.

41. Taylor, D.D.; Gercel-Taylor, C. MicroRNA signatures of tumor-derived exosomes as diagnostic biomarkers of ovarian cancer. Gynecol. Oncol. 2008, 110, 13-21. [CrossRef]

42. Zhou, J.; Gong, G.; Tan, H.; Dai, F.; Zhu, X.; Chen, Y.; Wang, J.; Liu, Y.; Chen, P.; Wu, X.; et al. Urinary microRNA-30a-5p is a potential biomarker for ovarian serous adenocarcinoma. Oncol. Rep. 2015, 33, 2915-2923. [CrossRef]

43. Zhang, H.; Xu, S.; Liu, X. MicroRNA profiling of plasma exosomes from patients with ovarian cancer using high-throughput sequencing. Oncol. Lett. 2019, 17, 5601-5607. [CrossRef]

44. Penyige, A.; Marton, E.; Soltesz, B.; Szilagyi-Bonizs, M.; Poka, R.; Lukacs, J.; Szeles, L.; Nagy, B. Circulating miRNA Profiling in Plasma Samples of Ovarian Cancer Patients. Int. J. Mol. Sci. 2019, 20, 4533. [CrossRef]

45. Vilming Elgaaen, B.; Olstad, O.K.; Haug, K.B.; Brusletto, B.; Sandvik, L.; Staff, A.C.; Gautvik, K.M.; Davidson, B. Global miRNA expression analysis of serous and clear cell ovarian carcinomas identifies differentially expressed miRNAs including miR-200c-3p as a prognostic marker. BMC Cancer 2014, 14, 80. [CrossRef]

46. Yan, J.; Jiang, J.Y.; Meng, X.N.; Xiu, Y.L.; Zong, Z.H. MiR-23b targets cyclin G1 and suppresses ovarian cancer tumorigenesis and progression. J. Exp. Clin. Cancer Res. 2016, 35, 31. [CrossRef] [PubMed]

47. Shen, W.; Song, M.; Liu, J.; Qiu, G.; Li, T.; Hu, Y.; Liu, H. MiR-26a promotes ovarian cancer proliferation and tumorigenesis. PLoS ONE 2014, 9, e86871. [CrossRef] [PubMed]

48. Ying, X.; Wei, K.; Lin, Z.; Cui, Y.; Ding, J.; Chen, Y.; Xu, B. MicroRNA-125b Suppresses Ovarian Cancer Progression via Suppression of the Epithelial-Mesenchymal Transition Pathway by Targeting the SET Protein. Cell Physiol. Biochem. 2016, 39, 501-510. [CrossRef] [PubMed]

49. Guan, Y.; Yao, H.; Zheng, Z.; Qiu, G.; Sun, K. MiR-125b targets BCL3 and suppresses ovarian cancer proliferation. Int. J. Cancer 2011, 128, 2274-2283. [CrossRef] [PubMed]

50. Mak, C.S.; Yung, M.M.; Hui, L.M.; Leung, L.L.; Liang, R.; Chen, K.; Liu, S.S.; Qin, Y.; Leung, T.H.; Lee, K.F.; et al. MicroRNA-141 enhances anoikis resistance in metastatic progression of ovarian cancer through targeting KLF12/Sp1/survivin axis. Mol. Cancer 2017, 16, 11. [CrossRef] [PubMed]

51. Li, J.; Zhang, S.; Zou, Y.; Wu, L.; Pei, M.; Jiang, Y. miR-145 promotes miR-133b expression through c-myc and DNMT3A-mediated methylation in ovarian cancer cells. J. Cell Physiol. 2019. [CrossRef] 
52. Cui, Y.; She, K.; Tian, D.; Zhang, P.; Xin, X. miR-146a Inhibits Proliferation and Enhances Chemosensitivity in Epithelial Ovarian Cancer via Reduction of SOD2. Oncol. Res. 2016, 23, 275-282. [CrossRef]

53. Yan, M.; Yang, X.; Shen, R.; Wu, C.; Wang, H.; Ye, Q.; Yang, P.; Zhang, L.; Chen, M.; Wan, B.; et al. miR-146b promotes cell proliferation and increases chemosensitivity, but attenuates cell migration and invasion via FBXL10 in ovarian cancer. Cell Death Dis. 2018, 9, 1123. [CrossRef]

54. Wen, Z.; Zhao, S.; Liu, S.; Liu, Y.; Li, X.; Li, S. MicroRNA-148a inhibits migration and invasion of ovarian cancer cells via targeting sphingosine-1-phosphate receptor 1. Mol. Med. Rep. 2015, 12, 3775-3780. [CrossRef]

55. Shi, C.; Yang, Y.; Zhang, L.; Yu, J.; Qin, S.; Xu, H.; Gao, Y. MiR-200a-3p promoted the malignant behaviors of ovarian cancer cells through regulating PCDH9. Oncol. Targets Ther. 2019, 12, 8329-8338. [CrossRef]

56. Zhang, Z.; Zhang, L.; Wang, B.; Wei, R.; Wang, Y.; Wan, J.; Zhang, C.; Zhao, L.; Zhu, X.; Zhang, Y.; et al. MiR-337-3p suppresses proliferation of epithelial ovarian cancer by targeting PIK3CA and PIK3CB. Cancer Lett. 2019, 469, 54-67. [CrossRef] [PubMed]

57. Liang, T.; Guo, Q.; Li, L.; Cheng, Y.; Ren, C.; Zhang, G. MicroRNA-433 inhibits migration and invasion of ovarian cancer cells via targeting Notch1. Neoplasma 2016, 63, 696-704. [CrossRef] [PubMed]

58. Zhang, S.; Zhang, J.Y.; Lu, L.J.; Wang, C.H.; Wang, L.H. MiR-630 promotes epithelial ovarian cancer proliferation and invasion via targeting KLF6. Eur. Rev. Med. Pharmacol. Sci. 2017, 21, 4542-4547. [PubMed]

59. Yang, B.; Sun, L.; Liang, L. MiRNA-802 suppresses proliferation and migration of epithelial ovarian cancer cells by targeting YWHAZ. J. Ovarian Res. 2019, 12, 100. [CrossRef] [PubMed]

60. Jiao, Y.; Zhu, G.; Yu, J.; Li, Y.; Wu, M.; Zhao, J.; Tian, X. miR-1271 inhibits growth, invasion and epithelial-mesenchymal transition by targeting ZEB1 in ovarian cancer cells. Oncol. Targets Ther. 2019, 12, 6973-6980. [CrossRef] [PubMed]

61. Clarke-Pearson, D.L. Clinical practice. Screening for ovarian cancer. N. Engl. J. Med. 2009, 361, $170-177$. [CrossRef]

62. Resnick, K.E.; Alder, H.; Hagan, J.P.; Richardson, D.L.; Croce, C.M.; Cohn, D.E. The detection of differentially expressed microRNAs from the serum of ovarian cancer patients using a novel real-time PCR platform. Gynecol. Oncol. 2009, 112, 55-59. [CrossRef]

63. Gao, Y.C.; Wu, J. MicroRNA-200c and microRNA-141 as potential diagnostic and prognostic biomarkers for ovarian cancer. Tumour Biol. 2015, 36, 4843-4850. [CrossRef]

64. Zuberi, M.; Mir, R.; Das, J.; Ahmad, I.; Javid, J.; Yadav, P.; Masroor, M.; Ahmad, S.; Ray, P.C.; Saxena, A. Expression of serum miR-200a, miR-200b, and miR-200c as candidate biomarkers in epithelial ovarian cancer and their association with clinicopathological features. Clin. Transl. Oncol. 2015, 17, 779-787. [CrossRef]

65. Yokoi, A.; Matsuzaki, J.; Yamamoto, Y.; Yoneoka, Y.; Takahashi, K.; Shimizu, H.; Uehara, T.; Ishikawa, M.; Ikeda, S.I.; Sonoda, T.; et al. Integrated extracellular microRNA profiling for ovarian cancer screening. Nat. Commun. 2018, 9, 4319. [CrossRef]

66. Ren, X.; Zhang, H.; Cong, H.; Wang, X.; Ni, H.; Shen, X.; Ju, S. Diagnostic Model of Serum miR-193a-5p, HE4 and CA125 Improves the Diagnostic Efficacy of Epithelium Ovarian Cancer. Pathol. Oncol. Res. 2018, 24, 739-744. [CrossRef] [PubMed]

67. Ayaz, L.; Cayan, F.; Balci, S.; Gorur, A.; Akbayir, S.; Yildirim Yaroglu, H.; Dogruer Unal, N.; Tamer, L. Circulating microRNA expression profiles in ovarian cancer. J. Obstet. Gynaecol. 2014, 34, 620-624. [CrossRef] [PubMed]

68. Palma Flores, C.; Garcia-Vazquez, R.; Gallardo Rincon, D.; Ruiz-Garcia, E.; Astudillo de la Vega, H.; Marchat, L.A.; Salinas Vera, Y.M.; Lopez-Camarillo, C. MicroRNAs driving invasion and metastasis in ovarian cancer: Opportunities for translational medicine (Review). Int. J. Oncol. 2017, 50, 1461-1476. [CrossRef] [PubMed]

69. Loganathan, S.; Kandala, P.K.; Gupta, P.; Srivastava, S.K. Inhibition of EGFR-AKT axis results in the suppression of ovarian tumors in vitro and in preclinical mouse model. PLoS ONE 2012, 7, e43577. [CrossRef]

70. Zhou, X.; Hu, Y.; Dai, L.; Wang, Y.; Zhou, J.; Wang, W.; Di, W.; Qiu, L. MicroRNA-7 inhibits tumor metastasis and reverses epithelial-mesenchymal transition through AKT/ERK1/2 inactivation by targeting EGFR in epithelial ovarian cancer. PLoS ONE 2014, 9, e96718. [CrossRef]

71. Vang, S.; Wu, H.T.; Fischer, A.; Miller, D.H.; MacLaughlan, S.; Douglass, E.; Comisar, L.; Steinhoff, M.; Collins, C.; Smith, P.J.; et al. Identification of ovarian cancer metastatic miRNAs. PLoS ONE 2013, 8, e58226. [CrossRef] 
72. Jin, M.; Yang, Z.; Ye, W.; Xu, H.; Hua, X. MicroRNA-150 predicts a favorable prognosis in patients with epithelial ovarian cancer, and inhibits cell invasion and metastasis by suppressing transcriptional repressor ZEB1. PLOS ONE 2014, 9, e103965. [CrossRef]

73. Bhaumik, D.; Scott, G.K.; Schokrpur, S.; Patil, C.K.; Campisi, J.; Benz, C.C. Expression of microRNA-146 suppresses NF-kappaB activity with reduction of metastatic potential in breast cancer cells. Oncogene 2008, 27, 5643-5647. [CrossRef]

74. Wilczynski, M.; Zytko, E.; Szymanska, B.; Dzieniecka, M.; Nowak, M.; Danielska, J.; Stachowiak, G.; Wilczynski, J.R. Expression of miR-146a in patients with ovarian cancer and its clinical significance. Oncol. Lett. 2017, 14, 3207-3214. [CrossRef]

75. Li, J.; Liang, S.; Jin, H.; Xu, C.; Ma, D.; Lu, X. Tiam1, negatively regulated by miR-22, miR-183 and miR-31, is involved in migration, invasion and viability of ovarian cancer cells. Oncol. Rep. 2012, 27, 1835-1842. [CrossRef]

76. Fang, Y.; Xu, C.; Fu, Y. MicroRNA-17-5p induces drug resistance and invasion of ovarian carcinoma cells by targeting PTEN signaling. J. Biol. Res. (Thessalon) 2015, 22, 12. [CrossRef] [PubMed]

77. Turchinovich, A.; Samatov, T.R.; Tonevitsky, A.G.; Burwinkel, B. Circulating miRNAs: Cell-cell communication function? Front. Genet. 2013, 4, 119. [CrossRef] [PubMed]

78. Hannafon, B.N.; Ding, W.Q. Intercellular communication by exosome-derived microRNAs in cancer. Int. J. Mol. Sci. 2013, 14, 14240-14269. [CrossRef] [PubMed]

79. Nakamura, K.; Sawada, K.; Kobayashi, M.; Miyamoto, M.; Shimizu, A.; Yamamoto, M.; Kinose, Y.; Kimura, T. Role of the Exosome in Ovarian Cancer Progression and Its Potential as a Therapeutic Target. Cancers 2019, 11, 1147. [CrossRef]

80. Mihanfar, A.; Fattahi, A.; Nejabati, H.R. MicroRNA-mediated drug resistance in ovarian cancer. J. Cell Physiol. 2019, 234, 3180-3191. [CrossRef]

81. Zou, Y.T.; Gao, J.Y.; Wang, H.L.; Wang, Y.; Wang, H.; Li, P.L. Downregulation of microRNA-630 inhibits cell proliferation and invasion and enhances chemosensitivity in human ovarian carcinoma. Genet. Mol. Res. 2015, 14, 8766-8777. [CrossRef]

82. Yang, H.; Kong, W.; He, L.; Zhao, J.J.; O’Donnell, J.D.; Wang, J.; Wenham, R.M.; Coppola, D.; Kruk, P.A.; Nicosia, S.V.; et al. MicroRNA expression profiling in human ovarian cancer: MiR-214 induces cell survival and cisplatin resistance by targeting PTEN. Cancer Res. 2008, 68, 425-433. [CrossRef]

83. Pink, R.C.; Samuel, P.; Massa, D.; Caley, D.P.; Brooks, S.A.; Carter, D.R. The passenger strand, miR-21-3p, plays a role in mediating cisplatin resistance in ovarian cancer cells. Gynecol. Oncol. 2015, 137, 143-151. [CrossRef]

84. Li, X.; Chen, W.; Zeng, W.; Wan, C.; Duan, S.; Jiang, S. microRNA-137 promotes apoptosis in ovarian cancer cells via the regulation of XIAP. Br. J. Cancer 2017, 116, 66-76. [CrossRef]

85. Tian, S.; Zhang, M.; Chen, X.; Liu, Y.; Lou, G. MicroRNA-595 sensitizes ovarian cancer cells to cisplatin by targeting ABCB1. Oncotarget 2016, 7, 87091-87099. [CrossRef]

86. Huh, J.H.; Kim, T.H.; Kim, K.; Song, J.A.; Jung, Y.J.; Jeong, J.Y.; Lee, M.J.; Kim, Y.K.; Lee, D.H.; An, H.J. Dysregulation of miR-106a and miR-591 confers paclitaxel resistance to ovarian cancer. Br. J. Cancer 2013, 109, 452-461. [CrossRef] [PubMed]

87. Zamfir-Chiru-Anton, A.; Gheorghe, D.; Nitu, L.; Bertesteanu, S. Relaţia dintre metaloproteinaze şi răspunsul imun în cancer. Rom. J. Med. Pract. 2014, 9, 211-213.

88. Helleman, J.; Jansen, M.P.; Burger, C.; van der Burg, M.E.; Berns, E.M. Integrated genomics of chemotherapy resistant ovarian cancer: A role for extracellular matrix, TGFbeta and regulating microRNAs. Int. J. Biochem. Cell Biol. 2010, 42, 25-30. [CrossRef] [PubMed]

89. Chen, S.; Jiao, J.W.; Sun, K.X.; Zong, Z.H.; Zhao, Y. MicroRNA-133b targets glutathione S-transferase pi expression to increase ovarian cancer cell sensitivity to chemotherapy drugs. Drug Des. Dev. Ther. 2015, 9 , 5225-5235. [CrossRef] [PubMed]

90. Sun, K.X.; Jiao, J.W.; Chen, S.; Liu, B.L.; Zhao, Y. MicroRNA-186 induces sensitivity of ovarian cancer cells to paclitaxel and cisplatin by targeting ABCB1. J. Ovarian Res. 2015, 8, 80. [CrossRef]

91. Wu, D.D.; Li, X.S.; Meng, X.N.; Yan, J.; Zong, Z.H. MicroRNA-873 mediates multidrug resistance in ovarian cancer cells by targeting ABCB1. Tumour Biol. 2016, 37, 10499-10506. [CrossRef]

92. Chen, Y.; Gao, D.Y.; Huang, L. In vivo delivery of miRNAs for cancer therapy: Challenges and strategies. Adv. Drug Deliv. Rev. 2015, 81, 128-141. [CrossRef] 
93. Zong, C.; Wang, J.; Shi, T.M. MicroRNA 130b enhances drug resistance in human ovarian cancer cells. Tumour Biol. 2014, 35, 12151-12156. [CrossRef]

94. Chen, S.; Chen, X.; Xiu, Y.L.; Sun, K.X.; Zong, Z.H.; Zhao, Y. microRNA 490-3P enhances the drug-resistance of human ovarian cancer cells. J. Ovarian Res. 2014, 7, 84. [CrossRef]

95. Petrillo, M.; Zannoni, G.F.; Beltrame, L.; Martinelli, E.; DiFeo, A.; Paracchini, L.; Craparotta, I.; Mannarino, L.; Vizzielli, G.; Scambia, G.; et al. Identification of high-grade serous ovarian cancer miRNA species associated with survival and drug response in patients receiving neoadjuvant chemotherapy: A retrospective longitudinal analysis using matched tumor biopsies. Ann. Oncol. 2016, 27, 625-634. [CrossRef]

96. Meijer, L.L.; Puik, J.R.; Vivaldi, C.; Capula, M.; Vasile, E.; Kazemier, G.; Giovannetti, E. Modification of Drug Response in Cancer by MicroRNAs. In MicroRNAs in Diseases and Disorders; Peplow, P.V., Martinez, B., Calin, G.A., Esquela-Kerscher, A., Eds.; Royal Society of Chemistry: Cambridge, UK, 2019; pp. 416-451.

97. Tanaka, H.; Matsushima, H.; Mizumoto, N.; Takashima, A. Classification of chemotherapeutic agents based on their differential in vitro effects on dendritic cells. Cancer Res. 2009, 69, 6978-6986. [CrossRef]

98. Mollaei, H.; Safaralizadeh, R.; Rostami, Z. MicroRNA replacement therapy in cancer. J. Cell Physiol. 2019, 234, 12369-12384. [CrossRef] [PubMed]

99. Hutvagner, G.; Zamore, P.D. A microRNA in a multiple-turnover RNAi enzyme complex. Science 2002, 297, 2056-2060. [CrossRef] [PubMed]

100. Li, S.D.; Zhang, J.R.; Wang, Y.Q.; Wan, X.P. The role of microRNAs in ovarian cancer initiation and progression. J. Cell Mol. Med. 2010, 14, 2240-2249. [CrossRef] [PubMed]

101. Banno, K.; Yanokura, M.; Iida, M.; Adachi, M.; Nakamura, K.; Nogami, Y.; Umene, K.; Masuda, K.; Kisu, I.; Nomura, H.; et al. Application of microRNA in diagnosis and treatment of ovarian cancer. Biomed. Res. Int. 2014, 2014, 232817. [CrossRef] [PubMed]

102. Li, N.; Wang, L.; Tan, G.; Guo, Z.; Liu, L.; Yang, M.; He, J. MicroRNA-218 inhibits proliferation and invasion in ovarian cancer by targeting Runx2. Oncotarget 2017, 8, 91530-91541. [CrossRef] [PubMed]

103. Cheng, W.; Liu, T.; Wan, X.; Gao, Y.; Wang, H. MicroRNA-199a targets CD44 to suppress the tumorigenicity and multidrug resistance of ovarian cancer-initiating cells. FEBS J. 2012, 279, 2047-2059. [CrossRef]

104. Wang, F.; Chang, J.T.; Kao, C.J.; Huang, R.S. High Expression of miR-532-5p, a Tumor Suppressor, Leads to Better Prognosis in Ovarian Cancer Both In Vivo and In Vitro. Mol. Cancer Ther. 2016, 15, 1123-1131. [CrossRef]

105. Fu, X.; Li, Y.; Alvero, A.; Li, J.; Wu, Q.; Xiao, Q.; Peng, Y.; Hu, Y.; Li, X.; Yan, W.; et al. MicroRNA-222-3p/ GNAI2/AKT axis inhibits epithelial ovarian cancer cell growth and associates with good overall survival. Oncotarget 2016, 7, 80633-80654. [CrossRef]

106. Fukagawa, S.; Miyata, K.; Yotsumoto, F.; Kiyoshima, C.; Nam, S.O.; Anan, H.; Katsuda, T.; Miyahara, D.; Murata, M.; Yagi, H.; et al. MicroRNA-135a-3p as a promising biomarker and nucleic acid therapeutic agent for ovarian cancer. Cancer Sci. 2017, 108, 886-896. [CrossRef]

107. Dai, F.; Zhang, Y.; Zhu, X.; Shan, N.; Chen, Y. Anticancer role of MUC1 aptamer-miR-29b chimera in epithelial ovarian carcinoma cells through regulation of PTEN methylation. Target Oncol. 2012, 7, 217-225. [CrossRef] [PubMed]

108. Denoyelle, C.; Lambert, B.; Meryet-Figuiere, M.; Vigneron, N.; Brotin, E.; Lecerf, C.; Abeilard, E.; Giffard, F.; Louis, M.H.; Gauduchon, P.; et al. miR-491-5p-induced apoptosis in ovarian carcinoma depends on the direct inhibition of both BCL-XL and EGFR leading to BIM activation. Cell Death Dis. 2014, 5, e1445. [CrossRef] [PubMed]

109. Kleemann, M.; Schneider, H.; Unger, K.; Sander, P.; Schneider, E.M.; Fischer-Posovszky, P.; Handrick, R.; Otte, K. MiR-744-5p inducing cell death by directly targeting HNRNPC and NFIX in ovarian cancer cells. Sci. Rep. 2018, 8, 9020. [CrossRef] [PubMed]

110. Pecot, C.V.; Rupaimoole, R.; Yang, D.; Akbani, R.; Ivan, C.; Lu, C.; Wu, S.; Han, H.D.; Shah, M.Y.; Rodriguez-Aguayo, C.; et al. Tumour angiogenesis regulation by the miR-200 family. Nat. Commun. 2013, 4, 2427. [CrossRef]

111. Joshi, H.P.; Subramanian, I.V.; Schnettler, E.K.; Ghosh, G.; Rupaimoole, R.; Evans, C.; Saluja, M.; Jing, Y.; Cristina, I.; Roy, S.; et al. Dynamin 2 along with microRNA-199a reciprocally regulate hypoxia-inducible factors and ovarian cancer metastasis. Proc. Natl. Acad. Sci. USA 2014, 111, 5331-5336. [CrossRef] 
112. Ohyagi-Hara, C.; Sawada, K.; Kamiura, S.; Tomita, Y.; Isobe, A.; Hashimoto, K.; Kinose, Y.; Mabuchi, S.; Hisamatsu, T.; Takahashi, T.; et al. miR-92a inhibits peritoneal dissemination of ovarian cancer cells by inhibiting integrin alpha5 expression. Am. J. Pathol. 2013, 182, 1876-1889. [CrossRef]

113. Shi, H.; Shen, H.; Xu, J.; Zhao, S.; Yao, S.; Jiang, N. MiR-143-3p suppresses the progression of ovarian cancer. Am. J. Transl. Res. 2018, 10, 866-874.

114. Mateescu, B.; Batista, L.; Cardon, M.; Gruosso, T.; de Feraudy, Y.; Mariani, O.; Nicolas, A.; Meyniel, J.P.; Cottu, P.; Sastre-Garau, X.; et al. miR-141 and miR-200a act on ovarian tumorigenesis by controlling oxidative stress response. Nat. Med. 2011, 17, 1627-1635. [CrossRef]

115. Garzon, R.; Marcucci, G.; Croce, C.M. Targeting microRNAs in cancer: Rationale, strategies and challenges. Nat. Rev. Drug Discov. 2010, 9, 775-789. [CrossRef]

116. Raza, K. Clustering analysis of cancerous microarray data. J. Chem. Pharm. Res. 2014, 6, 488-493.

117. Ducie, J.; Dao, F.; Considine, M.; Olvera, N.; Shaw, P.A.; Kurman, R.J.; Shih, I.M.; Soslow, R.A.; Cope, L.; Levine, D.A. Molecular analysis of high-grade serous ovarian carcinoma with and without associated serous tubal intra-epithelial carcinoma. Nat. Commun. 2017, 8, 990. [CrossRef] [PubMed]

118. McDonald, M.E.; Salinas, E.A.; Devor, E.J.; Newtson, A.M.; Thiel, K.W.; Goodheart, M.J.; Bender, D.P.; Smith, B.J.; Leslie, K.K.; Gonzalez-Bosquet, J. Molecular Characterization of Non-responders to Chemotherapy in Serous Ovarian Cancer. Int. J. Mol. Sci. 2019, 20, 1175. [CrossRef] [PubMed]

119. Dahiya, N.; Sherman-Baust, C.A.; Wang, T.L.; Davidson, B.; Shih Ie, M.; Zhang, Y.; Wood, W., 3rd; Becker, K.G.; Morin, P.J. MicroRNA expression and identification of putative miRNA targets in ovarian cancer. PLoS ONE 2008, 3, e2436. [CrossRef] [PubMed]

120. Bodelon, C.; Killian, J.K.; Sampson, J.N.; Anderson, W.F.; Matsuno, R.; Brinton, L.A.; Lissowska, J.; Anglesio, M.S.; Bowtell, D.D.L.; Doherty, J.A.; et al. Molecular Classification of Epithelial Ovarian Cancer Based on Methylation Profiling: Evidence for Survival Heterogeneity. Clin. Cancer Res. 2019, 25, 5937-5946. [CrossRef]

121. Wang, C.; Armasu, S.M.; Kalli, K.R.; Maurer, M.J.; Heinzen, E.P.; Keeney, G.L.; Cliby, W.A.; Oberg, A.L.; Kaufmann, S.H.; Goode, E.L. Pooled Clustering of High-Grade Serous Ovarian Cancer Gene Expression Leads to Novel Consensus Subtypes Associated with Survival and Surgical Outcomes. Clin. Cancer Res. 2017, 23, 4077-4085. [CrossRef]

122. Li, L.; Cai, S.; Liu, S.; Feng, H.; Zhang, J. Bioinformatics analysis to screen the key prognostic genes in ovarian cancer. J. Ovarian Res. 2017, 10, 27. [CrossRef]

123. Luo, J.; Pan, C.; Xiang, G.; Yin, Y. A Novel Cluster-Based Computational Method to Identify miRNA Regulatory Modules. IEEE/ACM Trans. Comput. Biol. Bioinform. 2019, 16, 681-687. [CrossRef]

124. Kuhn, H.W. The Hungarian Method for The Assignment Problem. Nav. Res. Logist. Q. 1955, 2, $83-97$. [CrossRef]

125. Berge, C. Paths, trees, and flowers. Can. J. Math. 1965, 449-467.

126. Ding, L.; Feng, Z.; Bai, Y. Clustering analysis of microRNA and mRNA expression data from TCGA using maximum edge-weighted matching algorithms. BMC Med. Genom. 2019, 12, 117. [CrossRef]

127. Elias, K.M.; Fendler, W.; Stawiski, K.; Fiascone, S.J.; Vitonis, A.F.; Berkowitz, R.S.; Frendl, G.; Konstantinopoulos, P.; Crum, C.P.; Kedzierska, M.; et al. Diagnostic potential for a serum miRNA neural network for detection of ovarian cancer. Elife 2017, 6. [CrossRef] [PubMed]

128. Hu, X.; Macdonald, D.M.; Huettner, P.C.; Feng, Z.; El Naqa, I.M.; Schwarz, J.K.; Mutch, D.G.; Grigsby, P.W.; Powell, S.N.; Wang, X. A miR-200 microRNA cluster as prognostic marker in advanced ovarian cancer. Gynecol. Oncol. 2009, 114, 457-464. [CrossRef] [PubMed]

129. Huang, X.; Zhang, L.; Wang, B.; Li, F.; Zhang, Z. Feature clustering based support vector machine recursive feature elimination for gene selection. Appl. Intell. 2018, 48, 594-607. [CrossRef]

130. Dong, J.; Xu, M. A 19miRNA Support Vector Machine classifier and a 6miRNA risk score system designed for ovarian cancer patients. Oncol. Rep. 2019, 41, 3233-3243. [CrossRef]

(C) 2020 by the authors. Licensee MDPI, Basel, Switzerland. This article is an open access article distributed under the terms and conditions of the Creative Commons Attribution (CC BY) license (http://creativecommons.org/licenses/by/4.0/). 